\title{
Adolescent Girls as Quality Learners: Issues And Concerns- A Study in Higher Secondary Schools of JAMMU (J\&K)
}

\author{
Varsha Kapoor (iD and Vishav Raksha
}

The quality of education and its determinants have been a topic of attention since the beginning of formal education. The present paper focuses on the issue of quality education among adolescent girls in the Jammu district (Union Territory of Jammu and Kashmir). Out of five dimensions of quality education given by UNICEF, the first and foremost condition is the need to have 'quality learners' is taken into consideration. It is an exploratory study based on empirical data gathered from 240 adolescent girls studying in sixteen higher secondary schools of Jammu District. The factors like parents' education, monthly income of parents, family support, school environment, and good nutrition plays a vital role in making girls quality learners. Results show that cultural norms play an essential role in shaping the personality and choices of adolescent girls.

KEYWORDS: $\quad$ Adolescent Girls, Quality Education, Quality Learners

\section{INTRODUCTION}

India is indeed the fastest growing economy. The process of development in India considered many areas of societal importance. Education is one of them. Although literacy rate has been increased in the few last decades, but in this rush, the quality of education is somewhere compromised. Everybody aspires to gain knowledge or guidance for successful living. But the desire or enthusiasm to access school education to acquire knowledge, skills and new tools of analysis is one thing; to succeed in acquiring them and showing evidence in

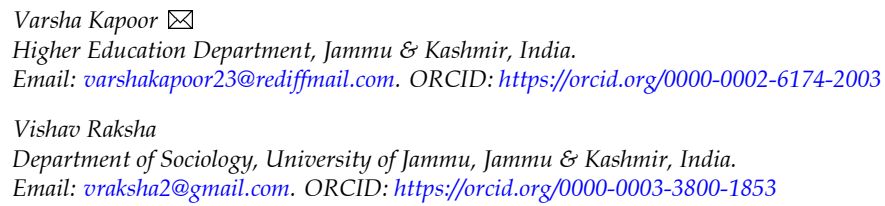


having acquired them in concrete terms is quite another especially in case of adolescent girls (Gyekye, 1987).

Education via formal secondary schooling is an important agent of socialization for adolescent girls. It is only through the creation of minds ignited with rational thinking that the unequal power structure can be questioned and altered. Girls can come forward and can actively participate in the development of the country (Sen, 1999). For a complex set of reasons, adolescents especially girls face enormous challenges to learn, form relationships, shape their identities and acquire the social and practical skills they need to become active and productive adults. A quality education is required which can help them in breaking the shackles of patriarchal structure of society and finally empower them in true sense (Fernandez \& Martinez, 2009).

The present paper considers the issues related to the quality of education provided to adolescent girls in higher secondary schools in Jammu district. Around half of the girls in the state do not get the chance to reach at secondary level education and those who fortunately get the opportunity do not get the required guidance and support to improve their prospects for an empowered living.

This research paper is an excerpt (considering one of the variables i.e., Quality learners) based on researchers' original work done on quality education. It mainly focusses on the issue of girls as quality learners. This period of Higher Secondary education coincides with the critical age of adolescence, when girls come up against the enormous societal and cultural pressures and thus more susceptible to various problems of the society. The focus of this paper is to analyse the problems related to girls to become 'Quality Learners' which is the first and foremost requirement of quality education (UNICEF, 2000). Emphasis is also given to contemporary challenges, and constraints that adolescent girls must face as learners in getting quality education.

For the present study, three measures of comparison were taken. Firstly, at broader level, a comparative study was conducted in rural and urban schools of Jammu District. Secondly, the focus was on evaluating the difference of school environment and related socialisation of girls studying in coeducation and single-sex or segregated schools in rural and urban areas. Thirdly, a comparison was made between girls studying in various government -funded and privately owned schools (both at state level board and CBSE) to analyse the difference in facilities and services which have a direct impact on the personality development and grooming of adolescent girls for a better life. 


\section{ReVieW OF THE RELATEd Literature}

For the present research, review of literature was done in context of adolescent girls' situation in India particularly in context of health issues and concerning factors was done.

It has been realised during literature review that in Indian society, the concept of 'adolescence' is not understood, as in the west. It is not viewed as an extended period of education and training for adult roles. There is limited scope of such experience in context of India. Reasons behind this limitation begins from factors such as a delay in the onset of puberty due to poor nutritional diet, prevalence of early marriage signifying adulthood to alarming crimes, safety issues and societal pressures (Bokova, 2015). Furthermore, the concept of generation gap cited in Western societies does not exist in India. Nevertheless, gradually, with the changing economic and social profile and structures, generational differences in India are becoming increasingly visible and unavoidable. The association of adolescence with sexuality is another factor which increases resistance to the concept, particularly regarding female adolescence (UNFPA, 2004).

'Girl Child in India: The Situational Analysis' (DWCD) points out that a large number of adolescents are undernourished, and the problem is more among girls (45 percent) than boys ( 20 percent), primarily due to deep-rooted gender discrimination. Girls need 10 percent more iron because of menstrual blood loss, but their consumption is much less. The most visible manifestation of nutritional deficiency is the high prevalence of anaemia and stunting among adolescent girls. Studies suggest that as many as 55 percent of adolescent girls may suffer from anaemia. Anaemia is exacerbated with pregnancy and often results in obstetric risks and reproductive failures. Anaemia is preventable with the consumption of iron tablets and nutrition supplements, and many government and NGO programmes are now addressing this problem (Department of Women and Child Development, 1999).

India's rapid economic advances over the last two decades are a cause of satisfaction. However, that satisfaction is allayed by the fact that several groups are being left out of these advances. One group, that rarely comes to mind but that badly needs to be brought into the centre of development, is adolescent girls. India lacks an institutional system to protect girls, as evident in the steadily deteriorating ratio of females to males, which declined from 972 females to 1,000 males in 1991 to 940 females to 1,000 males in 2011 (Census, 2011).

In context of India, Adolescent girls are huge in number i.e., 113 million amounting $20 \%$ of the world's adolescent girls but yet invisible. They are trapped in a conservative society with malpractices, discriminatory attitudes 
and lack of opportunities that leaves them powerless to make essential lifechoices and taking stand for themselves. As per the data gathered, those adolescent girls are particularly vulnerable in the States of Bihar, Rajasthan, and Uttar Pradesh. Half of all adolescent girls are forced to marry before the age of 18 , up to $95 \%$ of drop out of schools and over $50 \%$ face domestic violence (UNICEF, 2003). All this jeopardises the last chance for mediations that would help them in sustaining a healthy and empowered life thereafter. It is time for a long-overdue dialogue between civil society organizations, policymakers, and the private sector on what can be done to improve the lives of adolescent girls and enable them to fulfil their potential. There is an urgent need to place adolescent girls at the centre of development by understanding their environments and the challenges they face to design interventions that ensure safer, healthier cities where girls can fully develop their social and economic potential (Centre for Development and Population Activities , 2001).

Approximately 70,000 adolescent girls die each year from causes related to pregnancy and childbirth. Young women under the age of 18 face twice the risk of death during childbirth as women in their twenties. Many of them suffer long-term disabilities because of complications and/or poor health services during pregnancy and delivery.

Millions of adolescent girls, both married and unmarried face domestic violence, rape, sexual and dowry-related abuse, and exploitation, female genital mutilation/cutting and forced prostitution. It is estimated, for example, that 4 million women and girls worldwide are sold into marriage, slavery, or prostitution. Half of all victims of sexual abuse are under the age of 15 (UNICEF, 2003).

\section{Dimensions of Quality Education}

For the present research, the dimensions of quality education taken by UNICEF were taken into consideration.

UNICEF recognises five dimensions of quality (This paper is restricted to only one dimension of quality education i.e., 'Quality Learners'):

1. The learners who are healthy, well-nourished and ready to participate and learn and are supported in learning by their families and communities.

2. The environments that are healthy, safe, protective and gender-sensitive, and provide adequate resources and facilities.

3. Content that is envisioned and taught curriculum of schools. Quality content must consider national goals for education, and outcome statements that translate those goals into measurable objectives. 
4. Processes through which the teachers and administrators use inputs to frame meaningful learning experiences for students.

5. Outcomes which are planned, prospicient, intentional and expected out of learners (UNICEF, 2000).

\section{Objectives of the Study}

The study has the following objectives:

1. To explore the importance of adolescent girls as 'quality learners' in the process of quality education.

2. To understand the situation of adolescent girls as quality learners in various school environments

3. To analyse the contemporary challenges, problems, and constraints that adolescent girls must face as learners in getting quality education.

\section{STUdy AREA}

The present study was undertaken in the district Jammu. This is one of the important districts of the state Jammu \& Kashmir both in terms of education and its location. The district consists of 8 blocks and 4 tehsils. The district consists of a total number of 2414 Schools (J\&K School Education Department, 2013). There are $64 \mathrm{~J} \& \mathrm{~K}$ state government higher secondary schools (Directorate of School Education Department, DSEJ, 2013). As per the list of private schools, the estimated number of higher secondary schools is 200. Another important component of area selection was schools which follow Central Board of Secondary Education (CBSE) curriculum. There are around 40 CBSE higher secondary schools in Jammu district (government as well as private). All the higher secondary schools and the adolescent girls studying in them formed the population of the study. Schools were mainly divided based on rural and urban area (within the municipal limits).

\section{Research Design and SAmpling}

Keeping the objectives of the study in consideration the design chosen for the present research was 'Exploratory research design' which explored the issue under consideration. Quota sampling was made use of to select the respondents (Figure 1). From the sixteen quotas/categories, ten girls were chosen purposively (from different caste and class). It was realised during fieldwork that there was no school available as per the four categories chosen. So, the 
number of girls chosen from twelve (12) categories left was raised from 10 to 20 girls making a total sample of 240 girls.

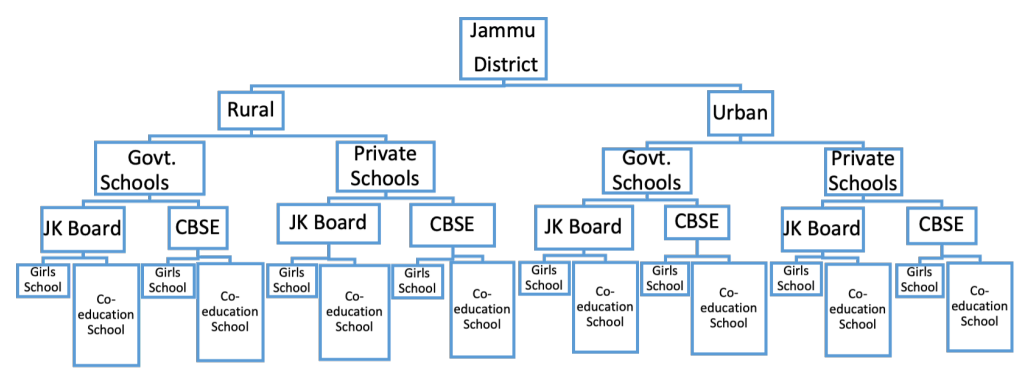

Figure 1. Graphical Representation of the Sample.

\section{Methods of Data Collection}

The present study is empirical and qualitative in nature and based on both primary and secondary data. The primary data is based on the intensive fieldwork carried out in various higher secondary schools of Jammu district. The secondary sources used included various books, articles, journals, archives. The sources available on internet are also considered. Observation, Questionnaire, Focussed Group Discussion were the major tools of data collection.

\section{FINDINGS OF THE STUdY}

\section{Adolescent Girls as Quality Learners}

In line with the first objective of the study, it has been realised that the learners' health, physical as well as mental is of utmost significance for acquiring education in schools. The quality of learners i.e., students who enrol in schools is the primary condition required for attaining desired outputs. Quality learner, here, includes health, early childhood experiences and home support. In case of adolescent girls, it has been realised that poor health (malnutrition, anaemia, low immunity, menstrual blood loss etc.) is the major reason for not attending the schools regularly affecting their learning abilities.

According to National Youth Policy (2014), 21.4 percent of the total population in India consists of adolescents UNICEF (2000). On average, most adolescent girls in India have little knowledge of menstruation, sexuality, and 
reproduction. Large numbers of rural and urban population believe that menstruation contaminates the body and makes it unholy. Therefore, the girl often sees herself as impure, unclean, and dirty. According to the Nutrition Foundation of India, the average age of menarche is 13.4 ; yet $50 \%$ of girls aged $12-15$ do not know about menstruation. This is true for rural as well as the urban poor. The lack of information can be attributed to a veil of secrecy that surrounds menarche. Thus, there is a need to pay attention to the requirements of this age group with special consideration to their different needs and situations.

\section{Situation of Adolescent Girls in Different School Environments}

With the objective of understanding girls' situation in schools as quality learners, girls were asked the questions related to frequency of girls falling sick, their scary experiences, support they receive from their family, regularity in school, reasons of absenteeism, educational qualification, and monthly salary of parents.

Girls in this transitional phase of life undergo rapid growth and development. Taking the case of India, many girls are nutritionally vulnerable and lack proper diet due to poverty, discrimination, and absence of adequate education of the importance of balance diet. They do not receive the attention they deserve and need. Low dietary intake is the most important cause of under-nutrition especially in girls. Many studies have analysed the minute incidences of inequality in day-to-day life where girls' meals (food, milk, fruits) etc. are even compromised for their brothers and fathers.

As per Table 1, Fever, cough, cold, body aches etc. are the general indicators of poor health. It was observed that according to more than $50 \%$ of the girls, they fall sick twice in a month and only $15.8 \%$ never fell ill. The girls of both rural and urban areas fall sick equally showing no major difference. One of the girls from a rural government school asked innocently, "maam, jo ek baar har mahine bimar hote hai uske ilava batana hai" (do I have to answer other than one time, I fall ill each month). It was also observed during focussed group interviews that many of the girls perceive themselves as ill during the monthly menstrual period and many of them did not go to school during those days.

Physical or mental abuse plays a negative role in the process of empowerment of adolescent girls. $65 \%$ of the girls marked that they never had any scaring experience while going to school or in the school while $35 \%$ agreed that they had some bad experience. Although major ratio of girls did not have any scary instance to remember but still $35 \%$ cannot be ignored either. Majority of girls who admitted that they suffered from some frightening incidents belong to rural areas and were studying in co-educational institutes (Table 2).

In a large-scale study conducted by the agency of the government of India 
Table 1

Frequency of Girls Falling Sick in a Month.

\begin{tabular}{lccc}
\hline S. No. & $\begin{array}{c}\text { Falling sick in a } \\
\text { month }\end{array}$ & $\begin{array}{c}\text { No. of } \\
\text { Respondents }\end{array}$ & Percentage (\%) \\
\hline 1 & Once & 43 & 18 \\
2 & Twice & 124 & 51.66 \\
3 & Weekly & 35 & 14.6 \\
4 & Never & 38 & 15.8 \\
\hline Total & & $\mathbf{2 4 0}$ & $\mathbf{1 0 0}$ \\
\hline
\end{tabular}

Table 2

Scary Experiences

\begin{tabular}{lccc}
\hline S. No. & Scary experience & $\begin{array}{c}\text { No. of } \\
\text { Respondents }\end{array}$ & Percentage (\%) \\
\hline 1 & Yes & 84 & 35 \\
2 & No & 156 & 65 \\
\hline Total & & $\mathbf{2 4 0}$ & $\mathbf{1 0 0}$ \\
\hline
\end{tabular}

on children covering around 3000 children aged from 5 to 18, it was realised that $65 \%$ of them have suffered from an incident of physical abuse at home and beaten up by teachers at schools. Poverty at home also clearly influenced school discipline practices. Living in poverty meant that children were sometimes not in a position to follow the rules and expectations of school.Children described being punished for not wearing uniform or not carrying the right equipment and not being able to pay fees (MOSP, 2012).

The attitude of the parents signifies that the supporting nature of family in their children's education is of great significance. The parental attitude can be negative or positive. The negative attitude of the parents regarding education and schooling can prevent their children from getting education. Lack of parental support in school assignments, low level of motivation and poor self-esteem of children can result in low educational outcomes. Positive attitude of the parents can be beneficial to their children in many cases and can be reflected in improvement in class performance, creating interest among children to learn, and higher achievement scores in reading and writing.

Although more than half of the girls (56.66\%) agreed that they were supported by their families, but they were reluctant to fill the option 'Whole- 
Table 3

Support Given by Family to Girls.

\begin{tabular}{lccc}
\hline S. No. & Family Support & $\begin{array}{c}\text { No. of } \\
\text { Respondents }\end{array}$ & Percentage (\%) \\
\hline 1 & Yes & 136 & 56.66 \\
2 & No & 24 & 10 \\
3 & Partially & 52 & 21.66 \\
4 & Whole-heartedly & 28 & 11.66 \\
\hline Total & & $\mathbf{2 4 0}$ & $\mathbf{1 0 0}$ \\
\hline
\end{tabular}

heartedly'. It was noticed that maximum girls who chose the option wholeheartedly were from urban private schools (Table 3). Girls cannot be empowered just by enrolling them in schools. Relational empowerment can only take place if the gender relations within family change and parents become more positive.

Table 4

Regularity of Girls in School.

\begin{tabular}{lccc}
\hline S. No. & $\begin{array}{c}\text { Regularity in } \\
\text { School }\end{array}$ & $\begin{array}{c}\text { No. of } \\
\text { Respondents }\end{array}$ & Percentage (\%) \\
\hline 1 & Yes & 200 & 83.33 \\
2 & No & 40 & 16.66 \\
\hline Total & & $\mathbf{2 4 0}$ & $\mathbf{1 0 0}$ \\
\hline
\end{tabular}

As shown in Table 4, Maximum number of girls i.e., $83.33 \%$ marked that they were regular in the school and only $16.66 \%$ admitted that they remained absent. It was also observed that private schools affiliated to CBSE in both rural and urban areas were more particular about the attendance of students than government schools following state board in both rural and urban areas.

As per Motiram and Osberg (2010), girls attending school share a double burden of doing household chores in comparison to boys. The trend follows in both rural and urban areas. It was largely found that the time consumed for doing household chores by both rural and urban girls increase with their age. The only difference is that in comparison to urban girls, rural girls spend more time performing household activities. Rural girls also experience the lowest rates for both enrolment and school attendance, with higher percentages of 
rural girls missing from school as they get older. In addition, the percentage of all children who do any homework given by school is lowest for rural girls. This provides evidence for one of the hypotheses that the opportunity cost of sending children to school (as opposed to engaging them in household activities) is higher for girls than for boys, and highest for rural girls.

Table 5

Reasons Behind Absenteeism of Girls.

\begin{tabular}{lcc}
\hline Reasons Behind Absenteeism & No. of Respondents & Percentage (\%) \\
\hline Health issues & 53 & 22 \\
Family problems & 67 & 27 \\
Long distance & 70 & 29.1 \\
Lack of interest & 18 & 7.5 \\
Poor financial status & 32 & 13.33 \\
\hline Total & $\mathbf{2 4 0}$ & $\mathbf{1 0 0}$ \\
\hline
\end{tabular}

Having an idea that many of them may not admit that they remain absent from the school, they were asked the reasons related to absenteeism in case of their friends too, in case they knew. An attempt was made to take them in confidence by convincing them that by doing this they were helping their friends. Majority of girls responded that long distance was the main reason of the absenteeism (29.1\%) followed by family problems (27.9\%), health issues (22\%), poor financial status (13.3\%) and lack of interest (7.5\%) (Table 5). It was also realised that schools in urban areas of all types were more particular about the attendance than schools in rural areas. However, private and CBSE affiliated schools in rural areas were better than government school of the state board in this context.

Long distance from the school to home is also a matter of concern for the girls' safety and absenteeism. In a case-study in Madanpur Khadar, South Delhi, the social dilemma, and plight of the school going girls was elaborated. A girl named Meena (not her real name) was not able to tell her parents that some boys bother her on her way to the school from her home. She was afraid that her family would not understand and will put all the blame on. Her fear came true when her parents banned her going out of the home, made her leave school and started searching for a match to get her married at the age of sixteen (Warner, 2013).

The educational status of parents is one of the significant factors which affects girls' secondary education. Due to existence of more illiterate people in rural areas, who have no knowledge about the benefits of educating girls, 
Table 6

Educational Qualification of Father.

\begin{tabular}{lccc}
\hline S. No. & $\begin{array}{c}\text { Educational } \\
\text { Qualification of Father }\end{array}$ & $\begin{array}{c}\text { No. of } \\
\text { Respondents }\end{array}$ & Percentage (\%) \\
\hline 1 & No qualification & 44 & 18.33 \\
2 & Primary & 68 & 28.33 \\
3 & Secondary & 32 & 13.33 \\
4 & Graduate & 52 & 21.66 \\
5 & Postgraduate and & 44 & 18.33 \\
& above/professional & & $\mathbf{1 0 0}$ \\
\hline
\end{tabular}

the girls must suffer. As per Table 6, there were $28.33 \%$ girls whose father was educated up to primary level, father of $18.33 \%$ girls were illiterate, $13.33 \%$ had secondary level education, $21.66 \%$ were graduates and $18.33 \%$ were postgraduates, who also had additional professional qualifications.

Burney and Irfan (1991) found that the girls of educated parents were more likely to admit in higher level schooling. They explained that levels of parents' education reflect the attitude and capacity to educate their children. They arrived at the conclusions that education of children is indirectly affected by their father's education. Father's education affects their children's education through their income. Conversely, mother's education has direct role in training, socialisation and developing the skills of their children.

A considerable literature has focussed on the effects of parental background on outcomes for their children such as cognitive skills, education, health, and subsequent income.

Illiterate parents keep no communication with teachers about their children's progress in school. In addition, educated parents regularly visit the school to update themselves about their children's progress in school. They facilitate their children in doing and completing homework. As they know the importance of education, they send their daughters and sons to school. Illiteracy of the parents negatively affects children's education especially their daughter education.

The ratio of the illiterate mothers was near to double than fathers i.e., $36.66 \%$ (Table 7). Most of them belonged to rural areas. Maximum girls whose mothers are postgraduates were from urban private schools both segregated and co-education. One important observation was that the mothers 
Table 7

Educational Qualification of Mother.

\begin{tabular}{lccc}
\hline S. No. & $\begin{array}{c}\text { Educational Qualification } \\
\text { of Mother }\end{array}$ & $\begin{array}{c}\text { No. of } \\
\text { Respondents }\end{array}$ & Percentage (\%) \\
\hline 1 & No Qualification & 88 & 36.66 \\
2 & Primary & 64 & 26.66 \\
3 & Secondary & 23 & 9.58 \\
4 & Graduate & 38 & 15.83 \\
5 & $\begin{array}{c}\text { Postgraduate and above/ } \\
\text { professional }\end{array}$ & 27 & 11.25 \\
\hline \multicolumn{2}{r}{ Total } & $\mathbf{2 4 0}$ & $\mathbf{1 0 0}$ \\
\hline
\end{tabular}

of most of the girls studying in the only private segregated school in the whole urban schools' category were more qualified than the fathers. Thus, it can be interpreted that more educated mothers prefer single-sex schooling for their daughters.

King (1990) noted that there is a positive impact of parents' education on 'completed years of schooling' of their daughters. In the same study, they found that mother's education had significant positive effects for daughter's education as compared to the son's education.

Mother's work status may exercise an independent influence over her children's educational chances, especially those of her daughters. According to the resource theory of conjugal power, in a family, decision-making power of both the parents depends upon the income or resources they bring to their family. Subsequently, women who are employed and are earning money have more decision making power in the family as compared to those who are not working. Thus, the women who are working by their own choice can create better prospects for their daughter's education whereas women who are forced to work due to poverty have to force their daughters to take care of the household chores and decrease their scope for getting education.

Monthly income of the family plays a major role in providing educational facilities to girls. It is one of the decisive factors in selection of schools for girls by the parents. There were $36.25 \%$ of total parents who had less than Rs 1000 monthly salary, the salary of $21.66 \%$ of parents was $10-20$ thousand rupees, $15 \%$ earned around $20-30$ thousand and $27.08 \%$ earned more than 30 thousand rupees a month (Table 8 ).

As per Table 9, out of 24 parents, $41.66 \%$ disagreed that spending on girl's 
Table 8

Monthly Salary of Parents.

\begin{tabular}{lccc}
\hline S. No. & $\begin{array}{c}\text { Monthly Salary } \\
\text { (in Rs.) }\end{array}$ & $\begin{array}{c}\text { No. of } \\
\text { Respondents }\end{array}$ & Percentage (\%) \\
\hline 1 & Less than 1000 & 87 & 36.25 \\
2 & $1000-20000$ & 52 & 21.66 \\
3 & $20000-30000$ & 36 & 15 \\
4 & 30000 and above & 65 & 27.08 \\
\hline & Total & $\mathbf{2 4 0}$ & $\mathbf{1 0 0}$ \\
\hline
\end{tabular}

Table 9

Views on Money Spent on Girl's Education (Views of Parents).

\begin{tabular}{lccc}
\hline S. No. & $\begin{array}{c}\text { Money Spent on Girl's } \\
\text { Higher Education is } \\
\text { Waste }\end{array}$ & $\begin{array}{c}\text { No. of } \\
\text { Respondents }\end{array}$ & Percentage (\%) \\
\hline 1 & Strongly Agree & - & - \\
2 & Agree & 04 & 16.66 \\
3 & Disagree & 10 & 41.66 \\
4 & Strongly Disagree & 10 & 41.66 \\
\hline & Total & $\mathbf{2 4}$ & $\mathbf{1 0 0}$ \\
\hline
\end{tabular}

education is a waste. $41.66 \%$ strongly disagreed to this statement while $16.66 \%$ agreed that money should not be spent on higher education of girls. One of the parents' said that he has five daughters, and he cannot afford their further studies. Three of them are doing part-time jobs to earn the money for their studies, thus continuing to study. Had they not been working he would have dropped out them from the school. He was worried only about their marriage and nothing else.

The parents generally have perception that spending on girl's education is like making charity to her husband and in-laws. There are less clear and more distant benefits due to the patriarchal structure where daughters traditionally marry out of their families and join their husbands. In this case parents may doubt how much they will benefit from having more-educated daughters.

Maximum parents i.e., 83.33\% strongly agreed that girls should be educated in girls only school (Table 10). Given a choice they would always admit their 
Table 10

Study in 'Only Girls' School (Views of Parents).

\begin{tabular}{|c|c|c|c|}
\hline S. No. & $\begin{array}{c}\text { Study in 'Only Girls' } \\
\text { School }\end{array}$ & $\begin{array}{c}\text { No. of } \\
\text { Respondents }\end{array}$ & $\begin{array}{c}\text { Percentage } \\
(\%)\end{array}$ \\
\hline 1 & Strongly Agree & 20 & 83.33 \\
\hline 2 & Agree & - & - \\
\hline 3 & Disagree & 04 & 16.66 \\
\hline \multirow[t]{2}{*}{4} & Strongly Disagree & - & - \\
\hline & Total & 24 & 100 \\
\hline
\end{tabular}

daughter in the girls' schools. They said that being the parents of a girl, they always feel a sense of worry when their daughter is out of home visualising the increasing incidents of crime. To their satisfaction, girls' schools are comparatively much safer places than co-education schools. At the same time, it is also realised that there are hardly any girls' only private/CBSE schools in both rural and urban areas. There is only one private CBSE affiliated higher secondary school in the Jammu district and admission to that school is based on qualifications of the parents and class to which the parents belong.

$16.66 \%$ of the parents disagreed that girls should be enrolled in segregated schools. Mother of one of the girls replied that she always prefers a coeducation school for both of her kids (girl and boy). She stated that, 'children should not feel alienated from the reality and learn to face the world along with the opposite sex from the initial years of life'.

\section{Issues, Challenges ANd Constraints}

After a detailed analysis of girls' situation and role of family and cultural norms, it has been realised that there are certain emergent issues which needs to be observed carefully for getting the solutions.

\section{Emergent Issues of Adolescent Girls that Creates Hindrance in Becom- ing Quality Learners can be categorised as:}

- Sexual maturation

- Consolidation of gender norms, including gender-based violence

- Changes in the family bond (e.g., parents' marital dissolution)

- Disproportionate care and domestic work burden for girls 
-Withdraw and/or lack of safety from public space for girls

- School leaving

- School safety for girls

- Loss of peers for girls

- Migration for work (often informal and/or unsafe)

- Subject to sexualizing and consumerist media

- Rising need for independent and disposable income \& assets

- Pressure for marriage as livelihoods strategies for girls (Judith \& Chong, 2006).

Adolescence is a critical developmental period for both boys and girls; yet, in many settings, girls face challenges during this period. While boys and girls are relatively equal in health and developmental outcomes during their early childhood, disadvantages mount for girls during adolescence. Girls experience a "density of transitions" during adolescence, in which biological and social changes tend to occur within a shorter period for girls than for boys UNICEF (2011). One-third of girls in the developing world are married before the age of eighteen, and one-third of women in the developing world give birth before the age of twenty (UNFPA, 2004).

\section{Data AnAlysis And Discussion}

It has been analysed through the findings of the study that formal quality education does not only depend upon the schooling patterns but many other social factors like poverty, lack of awareness, discrimination, lack of resources etc. Adolescent girls are the most nutritionally vulnerable group. Providing educational facilities at schools cannot help girls in their empowerment if they are not healthy. Health plays a major role in shaping their learning abilities. It is realised that more than half of the girls under study frequently fall ill (Table 1). Headaches, stomach ache, fever, cough etc. are the main health problems they suffer from Most of them are anaemic. They do not realise the importance of healthy diet and nutrition in living a healthy life. Poor health leading to lack of concentration and zeal is one of the hindrances in getting quality education among many girls. It is a basic need for the girls' cognitive empowerment. No major difference has been found in girls regarding their health studying in different schooling patterns. Thus, it is found that even in the present times, schools do not consider the health of students a major issue which needs attention. 


\section{Safe Environment}

More than half of the girls were reluctant to share any frightening experience but many of them have experienced something scary (eve-teasing, molestation, harassment, abuse etc.). As shown in Table 2, the ratio of rural girls studying in co-educational institutes in both private and government schools is greater than other girls who experienced it. It can be analysed that rural girls are more susceptible to such incidences due to the long distances they cover, lack of family support, lack of teachers who can built their confidence and lack of safety measures. It is also realised through observation and during FGDs that girls are hesitant to tell anyone about the trauma they went through. It is in line with many studies which shows that many a times the girls become victim of people known to her. It can be some relative or a teacher, so they silently bear the suffering due to the fear of embarrassment in the society they live. This is a major hindrance in the process of empowerment of girls.

\section{Support of Parents}

The support of the family and attitude of the parents is of great importance in getting quality education especially in case of adolescent girls. Parents play a major role in the cognitive, material, and relational empowerment of girls. Although as per more than half of the girls, their parents support them but out of the given options, most of them were reluctant in marking the option 'whole-heartedly' (Table 3). It is observed that most of the girls somewhere feel that their families do not happily and willingly support them in going to schools. One of the girls studying in rural government school expressed during FGD that she is good in studies and wanted to go to some good private school, but her parents enrolled her in government school (considering the financial status) and at the same time her two brothers were sent to private schools. Most of the girls who informed that their parents support them fully are the ones who were studying in urban private schools (both JK Board and CBSE) and few were studying in rural private schools. The parents who are comparatively more vigilant about the quality of education of their daughters prefer private schools in both urban and rural areas.

\section{Education Linked with Marriage Prospects}

Many a times, higher education for girls is considered as a barrier for marriage by some parents. Although more than half of the parents are in favour of girl education and want them to go for higher education, many of them belonging to rural area are afraid that they will not get the suitable match if the girl gets over-qualified (Table 9). The boys in their village are generally not highly qualified and started working at an early age. Such boys prefer a less educated girl for marriage. Parents in urban areas are much more supportive than in rural areas. 


\section{Parents' Preference for Segregated Schooling for Girls}

As shown in Table 10, given a choice, maximum parents want their daughters to study in an only girl's school. It is only due to the non-availability of such schools; they must send their daughters to co-educational schools. The parents who are highly qualified and studied in mixed schools want their daughters to go to mixed schools. They understand that it is important for their daughters to experience such environment as it is the reality of the society in which they are living. It can be analysed that parents' own experiences, perceptions and attitudes towards education and schooling have a significant impact on girl's education. Their educational status, financial status, locality, cultural set-up and thought process play a major role in cementing their views regarding education of adolescent daughters.

\section{Parents' Expectations Regarding Education}

Scoring good marks is the major outcome expected by parents from their daughters. They hardly worry about the values, skill- development, and personality enhancement of their daughter as significant consequences of education. All such aspects are given secondary and tertiary importance.

\section{Role of Mother's Education}

It is also observed that mother's work/job status may exercise an independent influence over her children's educational chances, especially those of her daughter. It is in line with the resource theory of conjugal power according to which, the degree to which parents influence on major household decisions depends on the extent to which they contribute essential resources into the family. One can infer from this that those mothers who are gainfully employed and contribute to the household income have more influence on family decisions than women who are not employed and educated (Table 7). Further, more independent women may be able to create better possibilities for their children, and especially for their daughter, to go to school. On the other hand, when the mother is forced to work because of poverty, the daughter may have to take over her household tasks and baby-sitting for siblings. This restricts girls from going to schools and sometimes, even if she is enrolled, she cannot concentrate on curriculum and other activities as her energy and strength is diverted and she is burdened with other responsibilities.

\section{Influence of Cultural Norms}

Cultural norms play a major role in shaping the choices of adolescent girls. Violence is dangerous for everyone and especially for adolescent girls who are themselves going through the phase of physical and emotional changes. Research shows that violence can affect many aspects of a girl's wellbeing and education. Understanding of violence and response to it varies from girl to girl in context of their cultural set-up, educational development, and socio- 
economic condition. Some girls narrated the incidents of raising their voice against injustice and violence during FGDs but the number was less. Some of them admitted that by doing so people around them think that schools are providing incorrect motivation as raising voice is not considered good for a girl's personality. People might think negatively which would ultimately affect their marriage prospects. Such thought process is impregnated with the deep-rooted gender bias in society where girls are constantly persuaded to tolerate the injustice as being normal and adjusting for their survival.

\section{Recommendations And Suggestions}

The following recommendations have been made based on the findings of the present study.

1. A holistic approach is required for the provision of quality education among the adolescent girls. For this, it is important to begin with quality learners. Best of the educational facilities and systems cannot work if the learners are weak, fragile, nutrition deficient and timid. Emphasising the importance of a well-balanced healthy diet and adequate physical activity at this age can go a long way in ensuring good health later. So, providing balanced and healthy diet at homes is necessary so that the health issues should not become a hindrance in attaining proper education.

2. As safety is one the major issues, efforts should be made at school level to introduce self-defence classes and secondly, girls should be encouraged to speak out openly about any trauma they have gone through so that the required action is taken. Steps like acquainting them with motivational stories of girls who fought for themselves from other parts of the country or world, life-situations of other girls in similar situations, making them aware of their rights and legal provisions etc. can be of immense help to them.

\section{Conclusions}

Quality education is an interplay of various factors beginning with quality learners and ending at quality outputs. Quality outputs can be achieved only if quality is ensured at the primary level. All the educational policies and programmes can go in vain if the learners are not prepared efficiently to gain the benefits of formal schooling.

Thus, a good education, a "girl-friendly" education, a "relevant" education, a quality education can do more to assure girls of a safe, productive and more empowered passage to adulthood than a typical or average education. If girls access good quality education which is provided in gender sensitive, safe and supportive environments created mainly by teachers in various educational 
institutions and parents at home, they may be able to develop self-awareness and confidence to overcome the broad challenges they face in the society.

\section{REFERENCES}

Bokova, I. (2015). Empowering adolescent girls and young women through education. A Joint Programme by UNESCO, UN Women, UNFPA and the World Bank, Paris. Retrieved from http:/ / www.youthmetro.org/ uploads/4/7/6/5/47654969/un_empowering_adolescent_girls _and_young_women_through_education.pdf

Burney, N. A., \& Irfan, M. (1991). Parental characteristics, supply of schools, and child school-enrolment in Pakistan. The Pakistan Development Review, 30(1), 21-62. Retrieved from https://www.jstor .org/stable/ 41259447

Centre for Development and Population Activities . (2001). Adolescent girls in India: choose a better future: an impact assessment. Retrieved from http://genderlinks.org.za/wpcontent/uploads/imported/ articles/attachments/13177_file_blp_report.pdf

Department of Women and Child Development. (1999). Girl child in India: the situational analysis. Retrieved from http://wcd.nic.in/ sites/default/files/AR2001-02.pdf

Fernandez, R., \& Martinez, A. (2009). The social and economic impact of illiteracy-analytical model and pilot study.

Gyekye, K. (1987). An essay on african philosophical thought. the akan conceptual scheme. Cambridge University Press.

King, E. M. (1990). Educating girls and women: investing in development. Washington DC.

MOSP. (2012). Children in india- 2012: A statistical appraisal report. India: The Ministry of Statistical and Programme Implementation.

Sen, P. (1999). Enhancing women's choices in responding to domestic violence in Calcutta: a comparison of employment and education. The European Journal of Development Research, 11(2), 65-86. https:// doi.org/10.1080/09578819908426739

UNFPA. (2004). UNFPA state of the world population 2004: the Cairo consensus at ten: population, reproductive health and global effort to end poverty. Retrieved from https://www.unfpa.org/publications/state -world-population-2004

UNICEF. (2000). Defining quality . Retrieved from https:// www.worldcat.org/title/defining-quality-in-education-a-paper -presented-by-unicef-at-a-meeting-of-the-international-working -group-on-education-florence-italy-june-2000/oclc/163823757

UNICEF. (2011). The state of the world's children. Retrieved from https:// www.unicef.org/reports/state-worlds-children-2011 
387 | Varsha Kapoor and Vishav Raksha

Warner, A. (2013). Education for girls: alternative pathways to girls' empowerment. Issue Paper Series. Retrieved from https://www.brookings.edu/wp-content/uploads/2016/07/ What-Works-in-Girls-Educationlowres.pdf 